\title{
The Experiences and Consequences of a Multiple Trauma Event from the Perspective of the Patient
}

\author{
Luciana Paiva $^{1}$ \\ Lídia Aparecida Rossi ${ }^{2}$ \\ Maria Cristina Silva Costa $^{3}$ \\ Rosana Aparecida Spadoti Dantas ${ }^{4}$
}

This was an ethnographic investigation with the aim of comprehending the meanings of the trauma experience among multiple trauma patients. The following techniques were used for data collection: direct observation, semi-structured interview and field diary. Biographical narratives were obtained from eleven trauma victims, and ten relatives as secondary informants. The data analysis considered the set of data of each participant and all data of all subjects, searching for differences and similarities. The meanings attributed to the trauma experience are associated with interrelated feelings of fear, insecurity, anger, vulnerability and suffering and to the meanings of quality of life that converge to valorize health and work appreciation and support by social networks. This analysis shows that the concepts and experiences of the trauma are conditioning factors of the health-disease process and they are essential in planning public health actions to meet the needs of individuals.

Descriptors: Quality of life; Multiple Trauma; Anthropology, Cultural; Qualitative Research.

\footnotetext{
${ }^{1}$ RN, M.Sc. in Nursing, Hospital de Clinicas, Universidade Federal do Triângulo Mineiro, MG, Brazil. Email: luciana.paiva@hotmail.com.

2 Ph.D. in Nursing, Full Professor, Escola de Enfermagem de Ribeirão Preto, Universidade de São Paulo, WHO Collaborating Centre for Nursing Research Development, SP, Brazil. E-mail: rizzardo@eerp.usp.br.

${ }^{3}$ Ph.D. in Social Anthropology Sciences, Professor, Escola de Enfermagem de Ribeirão Preto, Universidade de São Paulo, WHO Collaborating Centre for Nursing Research Development, SP, Brazil. E-mail: mccosta@eerp.usp.br.

${ }^{4}$ Ph.D. in Nursing, Associate Professor, Escola de Enfermagem de Ribeirão Preto, Universidade de São Paulo, WHO Collaborating Centre for Nursing Research Development, SP, Brazil. E-mail: rsdantas@eerp.usp.br.
}

Corresponding Author:

Lídia Aparecida Rossi

Universidade de São Paulo. Escola de Enfermagem de Ribeirão Preto.

Departamento de Enfermagem Geral e Especializada

Av. Bandeirantes, 3900

Bairro Monte Alegre

CEP: 14040-902 Ribeirão Preto, SP, Brasi

Email: rizzardo@eerp.usp.br 


\section{Experiência do paciente politraumatizado e suas consequências}

Esta é uma investigação etnográfica, realizada com o objetivo de compreender os significados da experiência do trauma entre pacientes politraumatizados. Foram utilizadas as seguintes técnicas de coleta de dados: observação direta, entrevista semiestruturada e diário de campo. Obtiveram-se narrativas biográficas de 11 pessoas, vítimas de traumas, e 10 familiares, como informantes secundários. A análise dos dados considerou o conjunto dos dados de cada participante e o todo dos dados de todos os sujeitos, buscando por diferenças e similaridades. Os sentidos atribuídos à experiência do trauma se associam a sentimentos inter-relacionados de medo, insegurança, revolta, vulnerabilidade e sofrimento e aos significados de qualidade de vida que convergem para a valorização da saúde, trabalho e apoio pelas redes sociais. Esta análise mostrou que as concepções e vivências do trauma são fatores condicionantes do processo saúde/doença e fundamentais para o planejamento de ações de saúde pública voltadas ao atendimento das necessidades individuais.

Descritores: Qualidade de vida;. Traumatismo Múltiplo; Antropologia Cultural; Pesquisa Qualitativa.

\section{Experiencia del paciente politraumatizado y sus consecuencias}

Se trata de una investigación etnográfica realizada con el objetivo de comprender los significados de la experiencia del trauma en pacientes politraumatizados. Fueron utilizadas las siguientes técnicas de recolección de datos: observación directa, entrevista semi-estructurada y diario de campo. Obtuvimos narraciones biográficas de 11 personas víctimas de traumas y 10 familiares, como informantes secundarios. El análisis de los datos consideró el conjunto de los datos de cada participante y el todo de los datos de todos los sujetos, buscando diferencias y similitudes. Los sentidos atribuidos a la experiencia del trauma se asocian a sentimientos interrelacionados de miedo, inseguridad, rabia, vulnerabilidad y sufrimiento y a los significados de calidad de vida que convergen para la valorización de la salud, trabajo y apoyo por las redes sociales. Este análisis muestra que las concepciones y vivencias del trauma son factores condicionantes del proceso saludenfermedad y fundamentales para la planificación de acciones de salud pública dirigidas a la atención de las necesidades individuales.

Descriptores: Calidad de vida; Traumatismo Múltiple; Antropología Cultural; Investigación Cualitativa.

\section{Introduction}

In recent decades, Brazilian epidemiological studies have indicated an increase in the rates of mortality, morbidity and disability caused by trauma, which configures it as a serious social problem. There are also serious economic repercussions, since this can not only impair the working capacity of the victims, but leads to high cost with rehabilitation due to temporary or permanent disability resulting from it. Furthermore, significant physical, mental and cognitive deficits, with impairment in the quality of life of victims and their families are among the possibilities of damage caused by trauma(1).

The increase in the number of survivors and the improvement in functional outcomes have led to greater concern regarding evaluating the quality of life of patients with multiple traumas. However, the focus of these evaluations is predominantly centered on measuring of objective aspects, often without considering the experience of those directly affected by the trauma. 
The survivors of severe trauma admitted to intensive care units have significant deficiencies related to the multiple complications resulting from a significant loss of muscle mass and cognitive deficits. Increasing age, cranial trauma, the length of the Intensive Care Unit (ICU) stay, preexisting diseases, the need for surgical procedures and lower limb fractures have been associated with worse quality of life outcomes ${ }^{(2-3)}$. The trauma can affect all parts of the body and its sequelae may differ substantially in the same way that the experience of the trauma victim is unique. Thus, the evaluation of quality of life has to consider these differences. It is observed in the literature that the aspects related to quality of life and health status have been mainly measured by instruments such as the SF-36(4), with the focus on adaptation after trauma and psychological problems involved in the development of post-traumatic stress.

A single study was found in the literature, conducted with a group of Chinese patients with spinal cord trauma, which focused on the cultural meanings of quality of life from the perspective of the group and identified five domains of quality of life, namely: physical, psychological, economic, social and environmental wellbeing (considering the aspects related to discrimination and government support) ${ }^{(5)}$.

Analysis of scientific publications in this journal, permitted the identification of articles that analyzed indices of trauma severity ${ }^{(6-7)}$ and evaluated the quality of life by means of generic instruments ${ }^{(4)}$, which strengthens the importance and the contribution of this study to the scientific community.

The anthropological perspective, applied to the health care area, provides resources that enable the apprehension of the experience of trauma and its cultural dimensions. In a heterogeneous and dynamic cultural context, as found in the contemporary societies, it becomes relevant to consider the distinct meanings socially attributed to disabilities, as well as the interpersonal relationships, practices, beliefs and social identity that permeate the experience of illness. This comprehension can stimulate care seen as humanitarian, in that it combines technical competence with respect for the human condition ${ }^{(8)}$.

Emerging trends point to the inclusion of the sociocultural context of the groups in health care, where their initial impulse refers to the development of Interpretive Anthropology ${ }^{(9)}$ and their influence on North American Medical Anthropology, from the $1970 \mathrm{~s}^{(10)}$. This framework justifies the construction of a new paradigm for the study of the relationship between health, illness and culture, emphasizing the cultural construction of illness and including the disease experience, from the logic of the patient, to explain and act in it.

The recognition of the importance of comprehending the experience of illness (in the case of trauma and its consequences) is the basis of this article. This study results from an ethnographic study conducted with multiple trauma patients, in the city of Uberaba, Minas Gerais, which sought to comprehend the cultural meanings of the experience of trauma. Thus, it aims to provide resources so that health professionals may identify aspects related to trauma through the valorization of the comprehension of the logic that guides the practices and concepts of a group of people who experience it.

\section{Methodological approach}

This ethnographic study was carried out between September 2007 and October 2008. This method is focused on the interpretation of the meanings of behavior, social relationships, rituals and values, linking them with the sociocultural context in which they are produced. This same intention is revealed in the analysis applied to health, under the inspiration of Medical Anthropology, which emphasizes the cultural construction of illness and the meanings that various groups and people attach to the health-disease process. Initially developed by a group of authors at Harvard University, Medical Anthropology provides important elements for the apprehension and analysis of the symbolic dimension of the disease. Among these resources, the distinction can be found between the explanatory models of illness in professional models (focused on the disease and its symptoms; developed in the field of science), and cultural models (with a popular basis, used by the patients and their families) ${ }^{(10)}$. Linked with this differentiation, Medical Anthropology establishes diverse concepts for the disease: disease refers to the disease process, the abnormality of the biological process, from the perspective of health professionals; illness corresponds to the subjective experience of the disease, related to conceptual model used by the patient to explain it and act.

Grounded in Interpretive Anthropology and Medical Anthropology, this study consists of interpretive analysis directed toward the comprehension of the meanings of the experience of trauma among multiple trauma patients. In pursuit of this comprehension, the analysis converges with the culture understood as webs of meaning spun collectively by man ${ }^{(9)}$, which reflect the historic diversity and social inequalities that characterize 
most human collectivities, the universe of meanings in terms of how individuals and groups interpret their experiences and guide their actions.

Highlighting the experience of disease (illness), comprehended in a symbolic context characterized by rules, meanings and specific social interaction, the study that led to this publication adopted the following criteria for the inclusion of subjects: people of either gender over eighteen years of age, residents of Uberaba, who suffered multiple traumas, admitted to the Intensive Care Unit of the University Hospital of the Federal University of Triangulo Mineiro, in the city of Uberaba/ MG, Brazil, between January 2005 and December 2006, and already discharged from hospital.

Thirty four possible participants were selected, from the patient records of all who met the inclusion criteria. After the selection of the data from the records, it was found that twelve patients had died and ten were not resident in the city of Uberaba. After the initial contact, eleven subjects agreed to participate in the study. Ten family members who fulfilled the role of caregivers to the subjects also participated as secondary informants, with only one of the protagonists of the research not having a family member caregiver.

The techniques used in the data collection process consisted of semi-structured interviews, direct observation, field diaries and biographical narratives, which allowed the interpretation of the meanings given by the participants to their experiences.

The semi-structured interviews, transcribed immediately after the close of each visit, were guided by the following initial requests: Tell me about the accident; Tell me what happened to you. The direction of the interviews prioritized the apprehension of the meanings of the trauma experience, the difficulties faced and the quality of life. For each of the study subjects a "narrative document" was structured, consisting of identification data, field notes, narratives transcribed in full, and data obtained from medical records. The data of each participant were analyzed separately and then related to those of the group of participants. From this process, the units of meaning were initially identified and grouped, these units were then categorized which allowed the construction of thematic nuclei.

This study was approved by the Research Ethics Committee of the School of Nursing of the University of São Paulo (Protocol no 0757/07). To identify participants, the following information was used: number of subject (S followed by number), Gender (Male M or Female F) and age.

\section{Results and Discussion}

The study group consisted of eight men and three women, between 18 and 49 years of age, mostly single and childless, with education levels between three and sixteen years of schooling (mainly elementary school) and low purchasing power (six had a monthly income at or below the minimum wage). All had suffered multiple traumas as a consequence of accidents: motorcycle (6), cycling (2), or other vehicle collision (1), and fall (2). The traumas mainly affected the following areas: skull (8); extremities (6); thorax (4); face (4) and abdomen (3). One patient suffered spinal cord injuries and three had no sequelae after the trauma. Seven had as the most important sequela the decrease in mobility, in addition, metabolic changes were mentioned such as hypercholesterolemia, diabetes mellitus; myeloid leukemia and tracheal stenosis. The mean length of hospitalization of the subjects was 32 days and in intensive care unit for 13 days (ranging from 3 to 84 days and 2 to 37 days respectively).

The narratives and behaviors of the participants allowed the verification that the meanings attributed by the subjects to the experience of trauma are related to the sequelae and identify, above all, with the difficulties faced. The meanings of the experience are associated with interrelated feelings of fear, insecurity, anger and vulnerability due to the emergence of pathologies caused by the trauma, the worsening of clinical symptoms and negative perceptions of body image and the mobility limitations. An important source of the attribution of meanings to the experience of suffering, also constructed based in feeling, is within the order of the sacred.

The statements and actions of the subjects also allow the apprehension of the meanings they attach to the quality of life, which converge to give priority to the valorization of health, of work and of support through social networks. In this case, a negative evaluation of the quality of life after the trauma is highlighted, with regard to health and work, however, it is represented positively, when associated with the family support network.

Personal identity, autonomy and the ability to work deeply structure the attribution of meanings to the experience of trauma, catalyzing the units of meaning identified in the statements and the actions of the study subjects.

\section{Facing the trauma: the initial moment}

Most participants explain that they know how the trauma occurred through the accounts of family 
members or people who witnessed the accident; their statements reveal no record of the event in the memory. Thus, the narratives begin with a recurrent phrase $I$ do not remember what happened.

In spite of the absence of memories, which probably wipe out an unbearable pain, the subjects elaborate explanations for what happened. The most frequent causes identified by them fall into the instance of the sacred (God's design), linked with individual behavior (use of alcohol and illicit drugs) or are linked to environmental and social deficiencies (the insecurity of the work environment and lack of warning signs).

For the most part, the memories evoked in association with the accident are related to the perception of changes in body image: ... I think it has changed my face a lot, my physiognomy is different and my arm is horrible as well (S2, M, 32). In relation to these initial images remaining in the memory, the study participants admit to having felt intense shame (some still do) due to the appearance of their body altered by the trauma, especially the fear of possible negative reactions from other people. The feeling of shame seems to anticipate how others will perceive them, define them, and tell them who they are. This is, in reality, the recognition of the relevance of how a change can affect, either temporarily or permanently, the personal identity of the subject which is, like any other, constructed in a relational way and has as partners in this construction those with close or distant relationships. Personal identity, which makes concrete an adjustment process of subjectivity to the social space, contains an internal, psychic aspect and another external, social aspect(11).

The memory is of intense physical and psychic pain. At that moment, the main apprehensions related to bodily changes, especially the loss of mobility, the capacity to work and the appearance. Some saw their worst fears confirmed: Sometimes I can not believe I had to use a nappy, eat with the syringe... When I was discharged from the Santa Casa, the doctor said to me: You will not walk anymore. I cried and told him: I want to try (S1, M, 30).

All subjects reported their search for comprehension for what they were living in the initial phase of adaptation, when faced with issues related to the search for meaning of suffering, the losses suffered and the life. They explain the triggering of a logic constructed in the sphere of the sacred as an important reference to respond to their metaphysical doubts and to support the facing of the difficulties experienced: When I was in ICU, I did not see myself in the hospital, I found myself in a place where someone else takes care me, it was the center (spirit) (S8, F, 38).
The reminiscences of the group reveal the key elements utilized by the subjects for the attribution of meaning to the experience in the initial moment facing the post trauma reality: body image, mobility, work, religion.

\section{The chronicity of the difficulties}

The study participants, at the time, perceived themselves as chronically ill, conceiving this "I am ill" as becoming physically dependent, not being able to work and being stigmatized through the changes provoked by the trauma. It seems that everyone looks at me as a poor fellow who is disabled because of my leg (S4, M, 27). The stigma, in this case, is unleashed by a particular health problem and the person becomes labeled, shunned and degraded by people close to them(12), not necessarily the family, and eventually the family and the subjects anticipate negative reaction from others.

They conceive themselves as ill also because they have their mobility reduced from the sequelae of the trauma: At the moment I feel I am not healthy, I am unable to do many things because of this breathing. So I think being healthy is being able to come and go. Sometimes I have the urge to take a walk and I can not... (S8, F, 38). This illness that remains in the lives of people with more severe sequelae is accompanied by feelings of anguish, emotional and spiritual suffering, pain and uncertainty, difficulties and stress factors that promote changes in well being, a reality also portrayed in the specialized literature(13).

The lives of people who suffered multiple trauma, with functional and aesthetic sequelae, undergo radical changes, which implicate various disabilities and changes in personal identity, the physical and mental conditions, the social status, employment, finances, life projects, religious aspirations and personal relationships ${ }^{(10)}$. The changes and disabilities configure the lived, in terms of medical knowledge, as a chronic health condition. However, it must be stressed that the chronic condition presents as a life experience surrounded by knowledge, perceptions and practices learned. Moreover, the experience of a chronic condition incorporates all the subject's social circle: family, friends, co-workers ${ }^{(10)}$.

The experience of a chronic condition triggered by trauma is represented by almost everyone as a biographical disruption, which radically changed the lifestyle and quality of life, work and social status, given the material problems that they face. Only one participant said that life had improved after the trauma; the other participants reported a feeling of vulnerability associated with the worsening of clinical symptoms and 
the emergence of new diseases, physical dependence, the inability to work and the use of medication.

In evaluating the quality of life after the trauma, the participants emphasized the reduction of monthly income resulting from the inability to continue work, decreased physical mobility, chronic problems and amnesia related to trauma. They highlight, conversely, the importance of the family in emotional support and in the rescue of the balance of financial life.

Due to the many negative experiences related to the lasting consequences of trauma, the individual with this chronic condition develops a fragmented selfimage. Suffering from chronic illness lies in the physical discomfort, in the constraints of life, in the changes of image and/or bodily function, in social isolation and in the loss of autonomy ${ }^{(14)}$. From what was observed among the subjects of this study and others, when the relationship between body and the self is mediated by religious, moral or spiritual values, the experience of suffering acquires meanings that promote the ability to redeem an integrated self-image ${ }^{(10)}$.

The subjects mentioned faith in God and support to cope with the situation experienced after trauma, and say: God is everything! God is resignation! First it has to be Him, then the other stuff! They recognize, like other members of the Brazilian popular classes, the existence of a higher power capable of acting on all things, a Being who directs life and brings security, peace and harmony in the face of suffering, uncertainty and anxiety ${ }^{(15)}$. The literature indicates belief and spirituality to be important conditioners for health and in particular for stress conditions $^{(13)}$. Only one of the participants in this study revealed not having religious beliefs and attributed the fact to the inequality of the experience of suffering among people. If God existed he could not make some suffer more than other people (S5, M, 26).

It appears from the statements that, in the illness process, the mobilized beliefs play a key role to attribute meaning to the suffering. These beliefs affect the perception and the understanding of the world, the set of possible alternatives for decision making and the selection of actions to be undertaken or not. Sometimes, I can't stand the pain in the legs, then I think it will pass and God helps me with this (S1, M, 30). Some authors also show that faith, independent of religion, is one of the important supports in the treatment of health and in the quality of life and that the spiritual mechanisms, such as experiences of connection with God or other deities, have great significance in the rehabilitation process of chronic conditions ${ }^{(16-17)}$.
Another important focus for the assignment of positive meaning to the experience - in that the participants recognize and encourage the treatment and the rehabilitation process - is the support networks.

For the study participants the family represented their primary support network, marking the process of facing the chronic condition in a positive way. No other support network is indicated by the subjects that, however, report changes in relationships with friends, adversely affecting the rehabilitation process: coexisting with other people got worse, people turn away from us and each one lives his life $(\mathrm{S} 8, \mathrm{~F}, 38)$.

Despite the consequences of the trauma (physical disabilities, changes in social relations, changes in lifestyle), several subjects assume that the experience resulted in better family life, and recognize that the improvement of family relationships was an important factor in the rehabilitation process. Family members were considered to be important caregivers in the illness process and in meeting the patient's basic needs. Some, as in the example of the following subject, mentioned that after the trauma, the family is everything, we became more united. Our family grew stronger (S6, F, 18). The possibility of activation of family support was understood by the group as a strategy that allowed the comprehension of the illness process and the positive reaction to the illness experience ${ }^{(18)}$.

The chronic condition, whether due to trauma or disease, makes individuals face physical limitations and situations that change the relationship of the person with work, with family, friends and partners. The insertion into networks of social support helps them to deal with these changes and to attribute meaning to the pain, the losses and difficulties. Among these support networks, the family is highlighted, in the promotion of wellbeing, emotional support, and partnership in the struggle with the changes ${ }^{(19-20)}$

\section{Body image, work and autonomy}

The perception of changes in body image and feelings related to the disability are found in the basis of attributing meanings to the trauma, among those that present more serious sequelae. They conceive themselves as disabled and this disability is mainly associated with the loss of mobility of parts of the body and with autonomy, the physical incapacity to work and to perform activities of quotidian living: I know I'm not going to manage to work as a dental prosthetist because I lost the movement of the left hand due to the surgery $I$ had on the tendon and this is a sequela for the whole of my life. [...]. I could not manage to load anything. (S2, M, 32). 
The dependence on others is highly problematic for individuals who suffered losses that compromise their mobility. When they conceived themselves as invalids, they always emphasize this dependence and the obstacles faced in their quotidian lives, including in their home, due to the inadequacy of buildings, vehicles, urban planning, public buildings, etc., for the special needs that are required.

Nine of the eleven study subjects resided in their own homes, in the suburbs of the city. The participants with major physical limitations revealed the many difficulties encountered in their domiciles, where the physical structure is not suitable for their needs: Here at home there is no structure for a wheelchair, I cannot enter the bathroom because the door is too narrow (S10, M, 37). Similar problems were found in other homes, as registered, for example, in the field diary of another participant of the research (S1, M, 30): a brick house with tiny rooms that hinder the movement of the wheelchair.

Obstacles to movement in a wheelchair are not limited, however, to the housing space. The patient who presented the most severe physical limitation among them all, referred to the difficulties encountered in the structure of the building where the Social Security Service is located which provides care: it is difficult to go there because last time I went, my brother had to carry me because they made the appointment in a place full of stairs (S1, M, 30). Regarding public services, the complaints are not limited to architectural barriers: the length of the processes and the difficulty for the Brazilian National Health Service (SUS) to perform expensive tests were indicated by the group, as relevant obstacles to the rehabilitation process.

The invalid condition that they attribute to themselves, characterized by loss of bodily mobility, related, invariably, to two qualities which they conceived as essential to the complete human being: work capacity and autonomy. Regarding autonomy, they see themselves as deprived of even the simple, quotidian activities. The inability to work emerges as the major impediment to family welfare and the realization of life projects. To return to work is seen as a dream of material comfort for the family and a life fully integrated into society: ...working to ensure a better future for myself and my daughter. I have to believe I'll get it all, if not, I'll be sad to have passed through everything I have and not to have the right to the good side of life (...) to be able to see my daughter study (S6, F, 18).

Faced with the inability to work, those who are no longer the same and miss their own lives are conceived as dependent, frail, ill and despised. It is possible to conclude from the interviews, that the condition of disabled, or invalid with which the subjects identify themselves, is linked to the loss of mobility and the ability to work, understood in turn as loss of autonomy. The meanings of invalid, equivalent to worthless and disabled reveal complete consistency with an urban and industrial society marked by the work ethic and subject to economic logic, which makes them devoid of value, not only for society but also for themselves. Work is therefore understood as a fundamental category in the construction of identity.

Also contributing to this negative redefinition of themselves are the visible signs of trauma inscribed on their bodies. Damage to physical appearance is conceived as deformation and ugliness by all those who have suffered changes in this way. For men and women, body image compromised by scar tissue, restriction of mobility of limbs, and tissue loss in the face, arms and legs reflected in lowered self-esteem. However, only among the women of the research group were particular reports found about the transformation of the marital relationship, which seem to indicate an issue relative to gender. They said they had received rejection from their husbands, boyfriends or partners and attribute the change to the sequelae of the trauma: He had difficulty accepting my scars and my dependence after the accident (S3, $M, 19)$. This difficulty of the companions was perceived by the women with feelings of frustration and anger and it is important to note that in the group of ten caregivers participating in the research, there was only one male.

The changes brought by the trauma suffered, in the bodies of the research subjects, impacted on various aspects of their material, emotional and social lives. As a symbolic matrix that organizes the experience and the relationships with the social, natural and cosmological world, the body is covered by distinct meanings: individual and social. The bodily experience is a subjective reality shaped by individual perceptions (the individual body) but also an objective reality, shaped by the demands of life in society (the social body) ${ }^{(11)}$. The narratives show how the individual body, by being distant from that which society designates as bodily normality, appears as a source of many problems and much suffering.

On one hand, the individual body moves away from the social body because the individual is no longer able to perform their primary function as a member of society: to work. On the other hand, the body that moved everywhere, meeting friends, running with the children, working, now depends on others, imprisoning 
it and transformed it into a symbol of their deprivation of autonomy. The individual body, reinterpreted by the trauma, departs from the social body and from the self. This divorce between the individual body and social body is intensely perceived by the reactions of others - or the fear of them, expressed from the first moment after the injury - and triggers a series of revealing feelings of how social events impact on the experience of the trauma and in the construction of their meanings ${ }^{(12)}$. The meanings of the experience of the multiple trauma individual facing the body distanced from the social ideal (entire, with no visible signs, able to work, etc.) which becomes a source of restrictions and shame that permeates the personal identity reconstructed after the trauma.

\section{Final considerations}

The results allow a series of reflections on the field of public health. The analysis informed by Medical Anthropology shows that the experience of the trauma is lived more than just as an occasional situation, thus constituting an individual and social process that pervades and shapes the lives of these people. The sequelae of the trauma and their consequences demonstrate the need to combine experience and knowledge in the care for trauma victim patients, recognizing this as an active subject of their rehabilitation process and recognizing that this process is entirely permeated by the symbolic universe. The experience of trauma reflects an individual reference, which may be common to many but is experienced as biographical data and reflects the particular knowledge of each person. However, it also incorporates an intersubjective elaboration mediated by life in society and is informed by collectively produced meanings.

The inclusion of the perspective of individuals directly affected by trauma, with attention to their behavior, concepts and experiences, is essential for planning public health actions aimed at meeting the needs of the individual, but which recognize the importance of sociocultural conditioners in the health-disease process.

\section{References}

1. Melione LPR, Jorge MHP. Morbidade Hospitalar por causas externas no Município de São José dos Campos, Estado de São Paulo, Brasil. Epidemiol Serv Saúde. 2008;17:205-16.

2. Ulvik A, Kvåle R, Wentzel-Larsen $T$, Flaatten $H$. Multiple organ failure after trauma affects even long-term survival and functional status. Crit Care. 2007;11(5):R95.

3. Livingston DH, Tripp T, Biggs C, Lavery RF. A fate worse than death? Long-term outcome of trauma patients admitted to the surgical intensive care unit. J Trauma. 2009; 67(2):341-349.

4. Oliveira NLB de, Sousa RMC de. Injury diagnosis quality of life among motorcyclists, victims of traffic accidents. Rev. LatinoAm. Enfermagem. 2003; 11(6):749-56.

5. Hampton NZ, Qin-Hilliard DB. Dimensions of quality of life for Chinese adults with spinal cord injury: a qualitative study. Disabil Rehabil. 2004 February 18;26(4):203-12.

6. Nogueira LD, de Sousa RMC, Domingues CD. Severity of trauma victims admitted in intensive care units: Comparative study among different indexes. Rev. Latino-Am. Enfermagem. 2009 novembro-dezembro; 17(6):1037-42.

7. Malvestio MAA, de Sousa RMC. Predetermining value analysis of the prehospital phase procedures in trauma victims survival. Rev. Latino-Am. Enfermagem. 2008 junho;16(3):432-8.

8. Kleinman A, Benson P. Culture, moral experience and medicine. Mt Sinai J Med. 2006 October;73(6):834-9.

9. Geertz C. A interpretação das culturas. Rio de Janeiro: LTCLivros Técnicos e Científicos; 1989.
10. Kleinman A. Patients and Healers in the Context of Culture. Berkeley: University of California Press; 1981.

11. Noack J. Reflexões sobe o acesso empírico da teoria de identidade de Erik Erikson. Interação Psicol. janeiro/junho 2007;11(1):135-46.

12. Minayo MCS. O desafio do conhecimento. Pesquisa qualitativa em saúde. 9. ed. São Paulo: Hucitec; 2006. 406 p.

13. Delgado C. Sense of coherence, spirituality, stress and quality of life in chronic illness. J Nurs Scholarsh. 2007;39(3):229-34.

14. Canesqui AM. Olhares socioantropológicos sobre os adoecidos crônicos. São Paulo: Hucitec/Fapesp; 2007.

15. Minayo MCS. Saúde-doença: uma concepção popular da etiologia. Cad Saúde Pública. 1998 abril;14(2):421-8.

16. Maruyama SAT, Zago MMF. The sickening process of colostomy patients by cancer. Rev. Latino-Am. Enfermagem. 2005 março-abril;13(2):216-22.

17. Narayanasamy A, Clissett P, Parumal L, Thompson D, Annasamy S, Edge R. Responses to the spiritual needs of older people. J Adv Nurs. 2004 October;48(1):6-16.

18. Baptista MN, Alves GAS, Santos TMM. Suporte familiar, auto-eficácia e lócus de controle evidências de validade entre os construtos. Psicol Cienc Prof. 2008;28(2):260-71.

19. Schnyder U, Büchi S, Mörgeli H, Sensky T, Klaghofer R. Sense of coherence - a mediator between disability and handicap? Psychother Psychosom. 1999 March-April;68(2):102-10.

20. Rena F, Moshe S, Abraham O. Couples' adjustment to one partner's disability: the relationship between sense of coherence and adjustment. Soc Sci Med. 1996 July;43(2):163-7.

Received: Sep. $20^{\text {th }} 2009$

Accepted: Jul. $16^{\text {th }} 2010$ 